\title{
The Dark Side of
}

\section{Independence: Paramilitary}

\section{Violence in Ireland and Poland}

\author{
after the First World War
}

\author{
J U L A E I C HE N B E R G
}

\begin{abstract}
This article analyses excesses carried out against civilians in Ireland and Poland after the First World War. It shows how the absence of a centralised state authority with a monopoly on violence allowed for new, less inhibited paramilitary groups to operate in parts of Ireland and Poland. The article argues that certain forms of violence committed had a symbolic meaning and served as messages, further alienating the different ethnic and religious communities. By comparing the Irish and Polish case, the article also raises questions about the obvious differences in the excesses in Poland and Ireland, namely in terms of scale of the excesses and the number of victims and, central to the Polish case, the question of antisemitism.
\end{abstract}

In the aftermath of the First World War, violence proliferated in many parts of Europe. The war ushered in a significant reshaping of the political landscape of Europe and the structure of its people and societies. Empires fell apart. New states emerged among the ruins. The experience of war altered the perception of the world and triggered changes regarding norms and values. Among the emerging states were Poland and the Irish Free State. The fundamental changes in the countries in question

Centre for War Studies, Department of History, Trinity College Dublin, Dublin 2, Ireland; eichenbj@tcd.ie. The present article is based on research undertaken in the project 'Paramilitary Violence after the First World War, I9I 8-I923', funded by the Irish Research Council for Humanities and Social Science (IRCHSS), and co-ordinated by John Horne (Trinity College Dublin) and Robert Gerwarth (University College Dublin). The author would like to express her gratitude for the intellectual input and criticism provided by discussions in the project and while presenting versions of this article in Dublin, at the European University Institute, Florence, and to the International Society for First World War Studies. The author would particularly like to thank John Horne and the anonymous readers for their input. All translations of quotations from untranslated sources are by the author. 
were accompanied by outbursts of violence. This article argues that violence against civilians served as a central element in the establishment of social identities that came to define the Irish and Polish nations. Paramilitaries were the most prominent perpetrators and initiators of such violence in both countries.

Ireland and Poland had both been an integral part of nineteenth-century European empires. Due to the nature of the respective empires, ${ }^{1}$ the history of both countries and the impact of the empires had differed, but they shared the common experience of being under foreign rule for a long period. Both Ireland and Poland became independent only after the First World War. The process of independence was different, but the trigger was the same: independence was made possible because the occupying empires had been shattered (as in the case of the Habsburg, the German, and the Russian empires) or shaken (as in the case of the United Kingdom) in the course of the war.

In the transitional period after the First World War, the lack of state control in both countries facilitated the rise of violence under the veil of a national struggle for independence. Military and paramilitary formations alike engaged in violence, sometimes supported or cheered on by a civilian crowd. This was especially the case in times and places where state institutions were absent or weak and unable to monopolise force. In both countries a large number of assaults on civilians occurred in this period, the fighting being dominated by irregular warfare such as guerrilla and civil war.

The history of the struggle for national independence in both countries has so far been written predominantly in military, political and institutional terms. However, the period was shaped precisely by the absence of functioning institutions, when power was seized by those who were able to do so. This article chooses to emphasise the cultural history of violence over political or military narrative history. ${ }^{2}$ Paramilitary combatants, prominent in regions of weak statehood after the First World War, embody the blurred distinction between 'military' and 'civilian' in the post-war period. Analysing assaults against civilians committed by these military, yet non-state-controlled, perpetrators adds to an understanding of violence arising in regions and times with no state monopoly of power. In particular, the article will aim to provide an insight into the emergence of violence against minorities during the wars of independence. This issue will be explored by discussing three forms of violence committed against civilians that were common in both Poland and Ireland: shootings, hair-shearing and arson. The point of the comparison is to identify common characteristics of the armed struggle for national independence as well as to distinguish national particularities. The article discusses the impact of the experience of the World War as well as that of the preceding occupation on the excesses against national and religious minorities in the context of a national struggle

\footnotetext{
1 See Julia Eichenberg and John Paul Newman, introduction to this issue, I 83-94.

2 John Horne and Alan Kramer 'War between Soldiers and Enemy Civilians, I9I4-I9I5', in Roger Chickering and Stig Förster, eds., Great War, Total War: Combat and Mobilization on the Western Front, 1914-1918 (Cambridge University Press, 2000), I 53-68, I6I-2.
} 
for independence. It thus contributes to a discussion of the social roots of violence against civilians in Ireland and Poland, as have been analysed in other settings. ${ }^{3}$

The article focuses on physical violence. However, both case studies show a high frequency of psychological violence, imposed by threats, fear and suspicion, and its impact. ${ }^{4}$ Even physical violence contained psychological aspects in so far as the violence committed also transmitted a message to the broader community. The impact of violent outbursts on public discourse and its function as political and social messages are what I call the semiotics of violence. ${ }^{5}$ Central to the process of violent excesses and the building and consolidation of a nation were dichotomies such as male/female, Catholic/non-Catholic, soldier/civilian, nation/minority. By committing assaults against the civilian population, the paramilitaries aimed to establish and to reinforce these dichotomies as a foundation for the new national community.

I shall first introduce the background of the Polish and Irish cases, then, second, present and discuss three typical forms of violence occurring in both countries before, third, discussing motivations and justifications for the violence committed in the context of nation-building in Ireland and Poland.

\section{Eastern Poland: the experience of war and the question of minorities}

Even though no accurate figures for the excesses seem to be available in either country, ${ }^{6}$ it is obvious that the scale of violence in eastern Poland far exceeded that

${ }^{3}$ For military violence against civilians see ibid. For ethnically motivated (crowd) violence see, e.g., the works of Natalie Zemon Davis and Stanley Tambiah. Fruitful insight might be gained from a comparison of crowd violence in these regions and crowd excesses taking place about the same period in Ulster. They are not part of this article, however, which concentrates on the territory of the Irish Republic. For a comparison of violence in the Six Counties and Upper Silesia, see Timothy Wilson, 'Ritual and Violence in Upper Silesia and Ulster, I920', Journal of the Oxford University History Society (Hilary, 2004), I-24. See also Wilson, 'Ghost Provinces, Mislaid Minorities: The Experience of Southern Ireland and Prussian Poland, I918-I923', Irish Studies in International Affairs, I3 (2002), 6I-86. Wilson's comparison here is highly enlightening. However, Wilson focuses on the comparison of Ireland with Upper Silesia, leading him to stress a major difference in both cases to support his arguments on violence: while the distinction in Ireland was sectarian, the distinction in Poland/Upper Silesia was about language ('Ghost Provinces', 64), and draws his conclusion abut the difference in violence from this. This article regards eastern Poland as a more promising comparative study, as religious and sectarian differences are as crucial as in Ireland.

${ }^{4}$ See Michael Geyer, 'Some Hesitant Observations Concerning "Political Violence", Kritika: Explorations in Russian and Eurasian History, 4 (2003), 695-708, 696.

5 The term 'semiotics of violence' was first used by Kostas Retsikas, 'The Semiotics of Violence: Ninja, Sorcerers, and State Terror in Post-Soeharto Indonesia', Bijdragen tot de Taal-, Land-en Volkenkunde, I62 (2006), 56-94. However, the use of the concept 'semiotics of violence' in this article does not particularly follow Retsikas's definition.

6 Statistics for the Irish war of independence suggest about 200 civilian casualties, I 50 of them in I92 I. Michael Hopkinson, The Irish War of Independence (Dublin: Gill \& Macmillan, 2002), 20I-2. No figure exists for civilian deaths in the Irish civil war, but military casualties are estimated at about 800 (government figures for January I922-April I924). Hopkinson, Green against Green: The Irish Civil War, 2nd edn (Dublin: Gill \& Macmillan, 2004), 272-3. About 250 are supposed to have died in Dublin during the fights over the Four Courts. Bill Kissane, The Politics of the Irish Civil War (Oxford University Press, 2005), 78. In eastern Poland, any attempt to give an accurate account for assaults and deaths was 
in Ireland. For Poland, the First World War did not end on I I November I9I $8 .^{7}$ Violence dominated the following years. The Polish east in particular became a playground for a highly diverse accumulation of combatants who turned not only against neighbouring armies but also against civilians, mainly 'suspect' minorities. The border wars took place in territories of the former empires that had mixed populations - 'shatter zones' of empires ${ }^{8}$ - and entailed violence against civilian members of ethnic, national and religious minorities. ${ }^{9}$

Poles had experienced the First World War as civilian victims of occupation and destruction, but also as soldiers. Polish men - men living in the territory of the later Polish state - fought as conscripts and professional soldiers in the armies of the occupying states: Germany, Russia and Austria-Hungary. About 800,000 Poles served in the Russian army, 300,000 in the Habsburg army and another 300,000 in German ranks. ${ }^{10}$ Some, who had the liberty to do so, engaged as volunteers in the

inhibited by the difficulties of reorganising local and state government control after the long period of territorial division. However, the casualties obviously exceed the Irish figures for military as well as civilian deaths. For some indications of the extent of violence see Piotr Wróbel, 'The Seeds of Violence: The Brutalization of an East European Region, I9I7-I922', Journal of Modern European History, I (2003), I25-48, I 38 . For discussions on the scale of Jewish casualties see Andrzej Kapiszewski, 'Controversial Reports on the Situation of Jews in Poland in the Aftermath of World War I: The Conflict between the US Ambassador in Warsaw Hugh Gibson and American Jewish Leaders', Studia Judaica 7 (2004), 257-304. Several commissions were set up to investigate antisemitic violence in Poland and published their results in reports. Israel Cohen, special commissioner of the Zionist Organisation in London, was the first to start enquiries into the situation in Poland in December I9I8. His report told of massive antisemitic pogroms and outrages, estimating the death toll of victims at about 800 . Israel Cohen, A Report on the Pogroms in Poland (London: Zionist Organisation, I9I9). See also Israel Cohen, 'My Mission to Poland (I9r8-I9I9)', Jewish Social Studies, I3, 2 (I95I), I 49-72. A following report provided by the US ambassador Hugh Gibson (appointed April I9I9) on the specific orders of the Foreign Ministry acknowledged the incidents, but adopted Polish reproaches about Jewish disloyalty and denied the existence of pogroms. Eventually, the Morgenthau Commission was set up in mid-I9I9 to verify the accounts. His report was more balanced than the first two, stating 'strong prejudices against Jews' as well as supporting some of the Polish arguments. The death toll according to Morgenthau's report was up to about 280 killed civilians (not including Ukrainians or Polish casualties). Kapiszewski, 'Controversial Reports', 293. Interestingly, a similar commission, the American Commission on Conditions in Ireland, was set up to report on events and excesses by the British Forces in Ireland. They collected evidence and Irish witness statements in the United States. See Katherine Hughes, ed., English Atrocities in Ireland: A Compilation of Facts from Courts and Press Records (New York: Friends of Irish Freedom, I92 I-2).

7 For the events of November I9I 8 and the shift from world war to independence to the following border wars in Poland see Piotr Lossowski, Zerwane Pęta. Usunięcie okupantów z ziem polskich w listopadzie 1918 roku (Warsaw: Panstwowy Instytut Wydawniczy, I986).

8 See Eichenberg and Newman, introduction; 'Borderlands: Ethnicity, Identity, and Violence in the Shatter-Zone of Empires since I 848' (2003-2007) at the Watson Institute for International Studies at Brown University, co-ordinated by Omer Bartov; Donald Bloxham, The Final Solution: A Genocide (Oxford University Press, 2009), 8 I ff.

9 Jörg Baberowski: 'Kriege in staatsfernen Räumen. Russland und die Sowjetunion I905-I950', in Dietrich Beyrau, Michael Hochgeschwender and Dieter Langewiesche, eds., Formen des Krieges (Paderborn: Schöningh, 2007), 29I-309.

10 See Waldemar Rezmer, 'Polacy w korpusie oficerskim armii niemieckiej w I wojnie światowej (I9I4-I918)', in Mieczysław Wojciechowski, ed., Społeczenstwo polskie na ziemach pod panowaniem pruskim w okresie I wojny światowej (1914-1918): zbiór studiów (Toruń: Uniwersytet Mikołaja Kopernika, I996), I37-48; István Deák, Beyond Nationalism: A Social and Political History of the Habsburg Officer 
Polish struggle for independence, within the ranks of the Polish Legions along with the Central powers, with Haller's Army (Błękitna Armia) in France, and the Polish Military Organization (Polska Organizacja Wojskowa, POW). More than 450,000 Polish soldiers died in the First World War and many more were wounded. ${ }^{11}$ As Poles were to be found on either side at almost any front, battles - especially at the Eastern Front - sometimes turned out to be fratricidal. After the official end of the war on I I November I9 8 Poland regained its independence, but found no peace. The Polish state gradually emerged behind the lines of the withdrawing powers of Russia, Germany and Austria-Hungary, but the consolidation of a central government and a state-controlled monopoly of the use of force took time. Poland's independence in I9I 8 entailed further warfare: defending - and expanding - the new Polish borders.

Official restructuring of the Polish forces to form the Polish army started even before the declaration of the Polish state (late October I9 I 8), with Polish government calls for all former legionnaires and officers to be sworn in for the Polish army in Warsaw. ${ }^{12}$ Most formations retained their structure and command and changed only their names. ${ }^{13}$ Ranks were filled with volunteers, individual demobilised soldiers and those who had been too young to serve during the war. During most of the period I 9 1 8-20 there was no functioning chain of command from Józef Piłsudski as the new head of state and official commander of the Polish army to the troops wandering the country. Even though the Polish Army was proclaimed before the existence of the new independent Polish state, in October I9I8, it is difficult to speak of a national Polish state army during the period in question. Only in March I920 did the demobilisation of the older soldiers and of the foreign Polish volunteers lead to reorganisation. ${ }^{14}$ The situation was the same in the north-east, especially in the Vilna region. ${ }^{15}$ In the meantime, Polish formations fought what, only at first sight, looked like a traditional state war. The aim of the Polish border wars was to secure and to

Corps, 1848-1918 (Oxford University Press, I990). Jan Rydek, W stużbie cesarza i króla. Generałowie $i$ admirałowie narodowości polskiej w siłach zbrojnych Austro-Wegier w latach 1868-1918 (Cracow: Księgarnia Akademicka, 200I),

11 Norman Davies, Im Herzen Europas: Geschichte Polens (Munich: C. H. Beck, 200I), I03; Rezmer, 'Polacy w korpusie oficerskim', I40.

12 Ossolineum, Wrocław, I2925/III I 885-I939; Karol Baczyński, 'Pamiętniki względnie Wspomnienia o ruchu I pracy niepodległościowej mojej I młodzieży polskej we Lwowie’ w latach od r. I885 do I9I 4, o służbie w Legionach Polskich i wojsku polskim w latach I9I4-I92 I oraz pracy społecznej od r. I924 do I935, Mikrofilm 2429, Zeszyt 5: I8 Nov. I9I 5-I 4 Nov. I9I8.

13 Rodowody i Symbolika Formacji Górnośląskich, I I Pułk Piechoty, set up in November I9I 8 with former POW members, filled ranks with former legionnaires, Polish soldiers from the former I 3 Austrian Schützenbataillon, and volunteers. Wojciech B. Moś, Wojsko Polskie i Organizacje paramilitarne (Katowice: Silesia, I997), 25-6.

14 The 3 Pułk Strzelców Podhalańskich was set up late October I9I9 on the basis of the 2 Pułk Instrukcyjny Grenadierów Woltyżerów of the Haller's Army. The 4 Pułk Strzelców Podhalańskich was formed in May I9I9 France from the I9 Pułku Strzelców Polskich (Haller's army). In June I9I9 it was transported to Poland and re-organised in September I9I9 according to new Polish standards. Its new name was I43 Pułk Piechoty Strzelców Kresowych. From October I9I9 it was employed against Ukrainians, then from March 1920 as 4 Pułk Strzelców Podhalańskich against Soviets. Ibid., 20-I, 24-5.

15 On 9 September, three months after the disarmament of Gen. Dowbór-Muśnicki’s corps, the Związek Wojskowych Polaków w Wilnie, was set up in Vilna, initiated by Maj. Bobiatynski,. They organised 
expand the territory of the new Polish state. But without a functioning chain of command, and engaging in excesses and banditry, it is more accurate to describe the Polish formations as paramilitaries, because although they were structured to become the core of a new army and had a military form, they were not yet state-controlled. Also their actions in the shatter zones and their participation in violence against civilians underlined their nature as paramilitary rather than military formations.

Rather than preventing the excesses against minorities, the domestic population often supported the perpetrators. The pogroms in Lwów and Kielce in November I9I 8 are just two outstanding examples of a widespread phenomenon of nationalist antisemitism. ${ }^{16}$ Considering the harm done to Poland and its population by the war, this was also caused by the extent to which the experience of the First World War led to an intensification of conflicts between the national communities living in these areas. ${ }^{17}$

\section{Southern Ireland: occupation and independence}

Violence in Ireland following the First World War far exceeded that experienced at home during the First World War. During the war only volunteers had joined the British army and they fought abroad; the Irish homeland had not been affected. Conscription was to have been introduced in I9I8, but it was met with fierce objection, and eventually the British government rethought its plans: Irishmen were not conscripted into the British army. After the end of the Great War, however, the Irish Republican Army (IRA) challenged the British crown forces, starting a war of independence that eventually ended British hegemony over the twenty-six counties which were to become independent Ireland. ${ }^{18}$

The IRA was structured to become the core of a new army once an independent state was established. And, indeed, large parts of the IRA became part of the Irish National Army, the Free State Forces of the new independent Irish republic. During the war of independence, the IRA fought as a para-state army rather than as a paramilitary force: ${ }^{19}$ it fought in the belief that it represented the new national army while another governmental power was (still) in place. While the Polish paramilitaries, without any control or central command, fought for their newly independent state, the Irish paramilitaries were fighting against the state. First, the IRA fought for its independence from what was understood as British colonisation. After the conditional

five artillery battalions and one battalion of Ulans. Among the new volunteers, officers of Dowbór formed the majority of the officer corps. Biblioteka Narodowa Zbiór Specjalny (BN Rękopisy), Rps BN akc I03 I2, Andrzej Brochocki: Wspomnienia wojenne z I 3-go pułku ułanów Wileńskich. Okres walk od Samoobrony Wileńskiej w I9I 8 r. do zawarcia rozejmu z Litwinami w I920 roku, 4 B.

16 Vejas Gabriel Liulevicius, Kriegsland im Osten. Eroberung, Kolonisierung und Militärherrschaft im Ersten Weltkrieg (Hamburg: Hamburger Ed., 2002), 432-6.

17 Frank M. Schuster, Zwischen allen Fronten. Osteuropäische Juden während des Ersten Weltkrieges (1914-1919) (Cologne: Böhlau, 2004), I72.

18 For details on the war of independence, see Hopkinson, War of Independence.

19 Robert Gerwarth and John Horne, 'Introduction', in Gerwarth and Horne, eds., Paramilitary Violence in Europe after the Great War, 1917-1923 (forthcoming). 
independence of the Irish Free State, as a self-governing British dominion, had been obtained, the IRA, opposed to the I92 I Anglo-Irish Treaty, fought the Free State Forces in the hope of gaining independence for all Irish territory. After the signing of the treaty the IRA was divided according to the new political cleavage lines: on the one side were the supporters of the Treaty, who regarded the decision of six counties of Ulster to remain in the United Kingdom as a bitter, but pragmatic, price to pay for state independence - and hoped eventually to regain them. On the other side were the republicans, who opposed the treaty as a betrayal of the Irish nation and continued to fight the new Free State Forces. The republican forces continued to call themselves the IRA, although they were already defined as the anti-treaty IRA. The civil war which followed led to a major split in Irish society and inhibited the development and consolidation of Irish governance.

During the war of independence the IRA did not have the means to fight the British forces, a situation that was repeated in the subsequent war against the Free State Army. In both instances, guerrilla warfare was adopted. The tactics of the war of independence and the following civil war abolished the traditional distinction between civilian and soldier, between wartime and private life. In clear distinction from what soldiers might have experienced during the First World War, there was no leave from guerrilla warfare. Likewise, the war was fought not only against the officials, but also against anyone connected to them: wives and families became the objects of threats and attacks. People were often suspected of treason, of passing on information, of betraying their home country just as it was finally about to become independent. The anger also turned against the Irish Protestants as representatives of a despised British colonialism. While the 'enemy from the outside' was identified as members of the British military forces, ethnicity and religion now defined the new 'enemy within'. ${ }^{20}$ Many assaults and excesses were committed in Ireland by the British Forces, especially the Black and Tans and the auxiliary forces during the war of independence. The First World War did not affect Irish territory, but the Anglo-Irish war of independence introduced violence to the Irish homeland. ${ }^{21}$ The experience of the war of independence and of British violence shaped the violence of the IRA against civilians both during the Anglo-Irish war and especially during the civil war. Acknowledging that the violence against civilians was two-sided, this article deals only with that committed by the IRA and not that of the British Forces.

\section{The semiotics of violence}

\section{Shootings}

During the struggle for national independence, the focus on achieving national unity easily allowed the use of violence against whomever might be considered an

20 Ibid.; Peter Hart, The IRA at War 1916-1923 (Oxford University Press 2003); Hopkinson, Green against Green.

21 On the question of how far the experience of the First World War by affected the behaviour of British soldiers in Ireland see Adrian Gregory, 'Peculiarities of the English? War, Violence and Politics I900-I939', Journal of Modern European History, I (2003), 44-59. 
external or internal enemy to the national cause. The shooting of civilians was one of the forms of lethal violence used in Poland and Ireland. However, there was an obvious perception that such killings were wrong, as the shooting of civilians was repeatedly blamed on the enemy, who was thereby presented as ruthless. ${ }^{22}$ In the Polish case, the urban guerrilla warfare of the battle of Lwów in November I9I 8 saw the civilian population caught between Polish and Ukrainian forces. ${ }^{23}$ Some were accidental victims of stray bullets, but others were deliberately targeted as Ukrainian and Polish formations alike killed suspect civilians as they executed prisoners of war, took hostages and terrorised the civilian population to enforce their rule over this region of mixed population. ${ }^{24}$ These shootings were mainly carried out on the assumption that the executed civilians had in reality been franc-tireurs or spies for the enemy. ${ }^{25} \mathrm{~A}$ paranoia regarding franc-tireurs and combatants in civilian clothes had been crucial to the occurrence of excesses against civilians throughout the First World War, and it continued to haunt the ethnically diverse regions in the east of Poland.

Antisemitism figured as one motivation in eastern Poland. In a well-known incident, Polish troops shot a significant number of civilians, the vast majority of them Jews, in the Polish-Lithuanian city of Vilna. The justification offered for these executions in the ensuing inquest was political, as the Jewish men were accused of collaboration with the Bolsheviks. ${ }^{26}$ However, this retrospective self-justification was not necessarily identical to the intentions and motivations at the time of the excesses. Similar shootings occurred in many other cities, one of the best-known incidents being the execution of Jewish men in Pińsk. ${ }^{27}$ Violence was exacerbated by rumours about Jewish militias shooting Polish combatants, which lowered the threshold of accepting shootings among the Poles. ${ }^{28}$ Aggression and fear built up a vicious circle of violence. ${ }^{29}$

22 Ossolineum, I2925/III I885-I939. Baczyński: 'Pamiętniki'. '[N]ew reports from Boruzia that Ukrainians burned down a Polish village and murdered [civilians] without any good reason.' Ibid., I94 (I I Nov. I9I 8).

23 Ossolineum, I2925/III i 885-I939. Baczyński: 'Pamiętniki', I 59 (I7 Oct. I9I 8), i65-6.

24 Wróbel, 'Seeds of Violence', I 38.

25 The term 'franc-tireur' originated in the Franco-Prussian war of I870-I and was used to describe irregular forces. John Horne and Alan Kramer, German Atrocities, 1914: A History of Denial (New Haven: Yale University Press 200I), I49-50 (quoted according to the German translation Deutsche Kriegsgreuel 1914. Die umstrittene Wahrheit (Hamburg: Hamburger Edition 2004), 9). Fear and 'autosuggestion' of combatants about civilians being franc-tireurs, about combatants dressing in civilian clothes and fighting a 'people's war' were used to justify assaults against civilians. Ibid., I24, I $50 \mathrm{ff}$. The franc-tireur myth also represented fears of death (ibid., I $73 \mathrm{ff}$., $200 \mathrm{ff}$.) and was used even by the military command to manipulate their troops (ibid., $202 \mathrm{ff}$.). For more details of the development of the franc-tireur myth see ibid., ch. 3 .

26 Przemysław Różański, Wilno, I9-2 I kwietnia I9I9 roku, Kwartalnik Historii Żydów/Jewish History Quarterly, I(2I7) (March 2006), I3-34, 2I-22.

27 Wróbel, 'Seeds of Violence', I 39.

28 David Engel, 'Lwów, November i9r 8: The Report of the Official Polish Governmental Investigating Commission', Kwartalnik Historii Żydów/Jewish History Quarterly, 3 (2 I I) (2004), 387-95, 39I.

29 Stanley Tambiah, Levelling Crowds: Ethnonationalist Conflicts and Collective Violence in South Asia (New Delhi: Vistaar Publications, I996), 236-7. 
The IRA claimed most shootings of civilians to be the execution of spies. However, these accusations were often based on mere assumptions and rumours. Shootings were not restricted to a certain geographical area or to any specific class. Spies in Ireland were not simply shot but were killed brutally, often with bullets in the face or riddling the body. Even poor a physical or mental condition did not prevent the IRA from carrying out its sentence. ${ }^{30}$ As a rule, notes were left on the corpses of victims of shootings with inscriptions such as 'Spy. By order IRA. Take Warning'. Some of the shootings are believed to have been linked to land disputes and social envy, as some victims were wealthy members of the Protestant ascendancy. ${ }^{31}$ However, the marginal social background of some other victims has been considered to be a more likely explanation for the killings. Ex-servicemen formed a large percentage of civilian victims, and many victims were working-class and impoverished, and had not been (re-)integrated into society after the war. In a context of raised tensions, isolated members of the communities were easy targets of suspicion and violence. ${ }^{32}$ The explanation that the majority of the killings had a sectarian background ${ }^{33}$ has been criticised and has been put into perspective by several other subsequent works. ${ }^{34}$

Another frequent form of shooting more closely related to combat was that of prisoners and of men who surrendered voluntarily to the IRA. Recalling an ambush in February I92I, the IRA member Maurice Meade described how one member of the British forces was shot, even though he had surrendered and was already disarmed, because he had been firing hidden under a lorry, which Meade regarded as treacherous. Two more prisoners were shot after being court-martialled by five IRA officers. Meade offered a more general explanation for the shooting than the immediate events, and argued that they had received an 'order from GHQ in Dublin that we were to shoot all Tans and peelers [police] who fell into our hands'. ${ }^{35}$

However, while shooting, and specifically the shooting of alleged spies, was widespread, not all suspect civilians were shot. The number of those suspected of disloyalty and treason was far in excess of those actually executed, and women suspected of spying were less likely to be shot than men. Instead, they were often singled out and shamed for their disloyalty. One way to do so was marking them as traitors by shearing their hair.

30 Borgonovo, John, Spies, Informers and the 'Anti-Sinn Fein Society': The Intelligence War in Cork City 1920-1921 (Dublin: Irish Academic Press, 2007), 42-5.

31 Hopkinson, Green against Green, 90-9I.

32 Borgonovo, Spies, 83, 9I-2.

33 This approach is still much discussed in the historiography on the subject. See, e.g., Peter Hart, The IRA at War, 1916-1923 (Oxford University Press); Hart, The IRA and Its Enemies: Violence and Community in Cork 1916-1923 (Oxford University Press, I998).

34 See, e.g., Charles Townshend, 'Historiography: Telling the Irish Revolution', in Joost Augusteijn, ed., The Irish Revolution, 1913-1923. (London New York 2002), I-I6.

35 National Archives of Ireland, Bureau of Military History: Witness Statement 89r: Maurice Meade: Private in the Casement Brigade, Germany; Section Commander, East Limerick Flying Column, $27-28$. 


\section{Shearing hair}

The cutting, shearing and shaving of hair was a form of violence frequently used in both Ireland and Poland, especially following accusations of betrayal. Similar excesses occurred in Belgium, where head-shaving was used to punish women who had become involved with Germans. ${ }^{36}$ After the Second World War shearing was taken up in several countries to humiliate and punish women 'traitors' ${ }^{37}$ One significant distinction in Ireland and Poland lies in the category of victims. In Ireland, the victims were almost exclusively women. ${ }^{38}$ Women were shorn on suspicion of spying, passing on information and betraying the new state. It was sufficient to be seen with the wrong men (members of the Crown forces, sons of well-off Protestants, or ex-soldiers of the British army). Men were shorn infrequently, and often in connection with more drastic forms of violence, as in the example of Timothy Mangan in County Kerry, who had his head shorn and his ear(s) cut off by 'armed and masked men' for being an alleged spy. ${ }^{39}$ Other forms of violent intimidation were used against men suspected of treason, such as tarring. ${ }^{40}$ The shearing of women therefore bears an explicit gendered, if not sexual connotation. ${ }^{41}$ Since women symbolised the fertility and the future of the young nation, their liaisons with the 'enemy' could not be tolerated.

In Poland, by contrast, the victims of shearing were predominantly Jewish men and the attackers aimed at their beards and their side-locks. ${ }^{42}$ This difference in the gender of the victims indicates differences in the intentions of the attackers. The

${ }^{36}$ Laurence van Ypersele, 'Sortir de la guerre, sortir de l'occupation. Les violence populaires en Belgique au lendemain de la Première Guerre Mondiale', Vingtieme Siecle, 83 (July-Sept. 2004), 65-74.

37 Fabrice Virgili, La France 'Virile': Les Femmes tordues à la Libération (Paris: Payot, 2000; Eng. translation: Shorn Women. Gender and Punishment in Liberation France, Oxford: Berg, 2002).

38 Incidents of women being shorn by 'armed and masked men' were frequent in the period between I 920 and I923. Some of the shearings followed a previous warning, almost all were left with a written or oral message that marked the shearing as punishment for being friendly with members of the Crown forces (during the time of British presence in Ireland), or for alleged betrayal of the IRA by passing on information. See the frequent reports, especially in the Irish Times and the Weekly Irish Times.

39 Irish Times, 'Outrage in Glencuttage', 26 Jan. I920, 4 (shorter article noting 'a portion of his ear' had been cut off), also 6 (longer, more narrative article stating both ears had been cut off).

40 The most common was tarring, sometimes feathering, the victim. Victims of tarring were, among others, Patrick Sheehy, editor of the Skibbereen Eagle newspaper, Irish Times, 25 June I920, 5; a war veteran in Tralee for allegedly being 'a candidate for the position of District Inspector in the RIC', Weekly Irish Times, I 8 Sept. I920, 3; a labourer in Miltown, Killarney, for speaking with soldiers, Irish Times, 25 Sept. I920, 8, also Weekly Irish Times, 2 Oct. I920, 3; a carpenter was tarred, allegedly for giving information to authorities, 'A Man Tarred', Irish Times, I5 Nov. I920, 5. Other forms of violence involved kidnapping or fake executions. In September I920 a publican in Cavan was blindfolded and kidnapped because his shop had been frequented by British soldiers. Irish Times, 4 Sep. I920, 5. At the same time reprisals aimed at the IRA sometimes included cutting the hair of men: 'following cutting of girls' hair in Ballinasloe two Sinn Féiners were taken from their beds by armed men. One of them had his hair cut off with a horse-clipper and the other man is missing.' 'Incidents in the Provinces', Irish Times, 26 Oct. I920, 4A.

41 This article does not deal with rape and sexual assaults, but they also took place - and are somewhat under researched in the historiography.

42 Kapiszewski, 'Controversial Reports', $279 \mathrm{ff}$. 
hair- and beard-cutting of Jewish men might be read as having an equalising function by nullifying their distinct religious appearance and making them look like other men. However, this explanation neglects some important aspects. First, the procedure was physically painful: a group of armed men would hold the victim down, often at gun- or knifepoint. The hair was cut brutally, mostly with a knife rather than scissors, cutting skin or ears or pulling out tufts of hair along with parts of the skin. Sometimes hair or beard was even set on fire. This form of violence is closely linked to the use of ancient weapons: fire and the knife. The knife is the most personal weapon, as it requires the immediate execution of violence by the perpetrator and leaves no space for anonymity between them and the victim..$^{43}$ Second, the procedure left the victim, woman or man, marked both physically and symbolically. The victim would be disfigured for weeks or months, in the worst case for life, as parts of the facial skin or the scalp would remain scarred and no longer grow hair. The symbolic aspect was very important in this form of violence. The shorn head was a statement that the perpetrators held the power of life and death over the body of the victim. It also carried a message and a warning to the victim's community.

The shearing of Irish women and Polish/Ukrainian Jews took place in different settings. The shearing of male Jews was in most cases a public procedure; the victims were cornered in public spaces such as a marketplace or street, and shorn before cheering bystanders. The shearing of women in Ireland took place predominantly in secluded spaces. The female victim was either visited at night in her home or trapped while wandering alone or in a small group. Often she was led or chased into the fields, where the actual shearing would take place under the observation and cheering of the male companions of the perpetrator(s).

The most obvious difference is the fact that one seems very obviously religiously motivated while the other is less so. Cutting the beard and hair of an orthodox Jew was violence - both symbolic and physical - aimed at a religious symbol. Shearing women, on the other hand, was primarily about betrayal, disloyalty and, to a certain extent, sexuality. By the same token the shearing of men might be seen as a form of emasculation and feminisation of the victim. But the Irish case, too, contained a religious element: mainly Irish Catholic women were victims of this treatment. During the war of independence, Black and Tans had shorn Irish women for taking part in IRA activities, or for withholding information on the IRA. IRA men, on the other hand, would use hair cutting as a punishment for women who allegedly had relations with British soldiers or were suspected of giving information about IRA activities. In both cases, Irish Catholic women were the principal targets. Protestant women were less likely to be punished for their relations with the British - even though they might have been targeted for passing on information. In these cases, the key accusation would be one of (alleged) betrayal. Which brings us back to the excesses against Jews in eastern Poland, as the predominant accusation was the same: betrayal of the emerging Polish nation.

43 Wolfgang Sofsky, Traktat über die Gewalt, 2nd edn (Frankfurt a.M.: Fischer, I996). Sofsky also calls it the most democratic weapon, as it provides anybody with the power to kill at any time. Ibid., $32 \mathrm{ff}$. 
The gender of the perpetrators was almost exclusively male in both countries. Women figure in these accounts as cheering bystanders, but only rarely are they mentioned as having actively taken part in the shearing and cutting. ${ }^{44}$ Still, the hair shearing in Poland and in Ireland display striking similarities. The assault implies public humiliation of the victims and carries a message and a warning to their own community. Attacks against honour and dignity were used to undermine prior norms and identities and to intimidate those who (potentially) offered cover to 'terrorists', to separate and alienate civilians from combatants. At the same time this form of violence was a public shaming to warn, to maintain conservative values within the community and to enforce communal boundaries. It might be assumed that punishing Irish Catholic women for 'being friendly with British soldiers' served not only a political purpose, but also maintained social hierarchies (the Catholic church and the traditional family) and dichotomies (male/female) in times of change, when the new regime and social order was not yet consolidated. The same might be said in the case of assaults against Polish Jewish men: the aggression, justified with suspicion of political disloyalty, was also an attempt to settle the question of minorities in the new nation-state before it was even raised. Double insecurity in terms of both social order and of security apparatus triggered the violence.

\section{Arson}

Arson was a third frequent form of violence in Ireland and in Poland. It was used by all sides during the conflicts. Allegedly, burnings had been introduced into the Irish context by the British Auxiliary troops as a form of reprisal and tactical violence. The IRA responded in kind, using arson as a weapon against Protestant landowners or to destroy or as a means of looting military barracks. ${ }^{45}$ At the same time, in eastern Poland, houses and shops of Ukrainians and Jews were burned down. ${ }^{46}$ Some of these incidents were carried out or inspired by soldiers and paramilitaries, others by an outraged crowd - although witness accounts frequently hint at incitement by paramilitaries.

Arson serves as the ultimate pragmatic attack in a paramilitary war. It is easy and cheap. It allows secrecy and publicity at the same time: secrecy for the perpetrator, who could get away in the shadow of the night - and publicity, since the fire would be noticed from far away. Even after the flames are extinguished, the charred ruins are a significant landmark, carrying a message and a warning.

44 One example being a case in Carlow where the daughter of 'a prominent public official' was stopped by a group of men and women (some accounts claimed women only). Witnesses and the victim claim the actual cutting was done by one of the young women, who had her face covered; 'Political motives are assigned for the outrage', Weekly Irish Times, Io July I920, 3.

45 Borgonovo, Spies, 93-94.

46 E.g. when the Jewish district of Lwów was burned down in late November i9i 8. Engel, Lwów, November I9I 8, 393-394. Accounts of arson and burnings committed by both sides are repeated frequently in memoirs and witness accounts. I.e. 'Ukrainians burned down a Polish village and murdered [several civilians] without any good reason.' Ossolineum, I2925/III i 885-I939. Baczyński: 'Pamiętniki', I94: (between I I Nov. I9I 8 and I4 Nov. I9I8). 
However, arson also had a deeper meaning. Fire is an ancient weapon with a strong religious symbolism of purification. ${ }^{47}$ Catholics burning Protestant estates, Irish Protestants burning Catholic houses, Polish Catholics burning Jewish shops and Ukrainian homes also symbolically cleaned and religiously purified their communities. Burnings stated that the offender had the power to decide over public space - and over life and death, thereby again referring to the symbolic notion of fire as a weapon. Chronically short of weapons, and looking for support among the 'national' civilian population (defined in ethnic and religious terms), Irish and Polish paramilitary forces made use of arson against both internal and external enemies. A fire could be fuelled by paramilitary perpetrators and then left to the enraged crowd, turning a political and tactical reprisal into a collective experience of violence, proof of a 'national uprising' of the people. The fire was supposed to purify, it was supposed to burn out the internal enemy and melt the nation into one.

\section{Legitimating violence against civilians: a discourse of religion and politics}

Discussions on how to evaluate violence after the First World War in Ireland and in Poland turn on two key concepts: 'sectarian violence' in Ireland and 'ethnic violence' in Poland. However, the violence occurring in both Ireland and Poland was more due to a discourse of nationality and national loyalty intertwined with the attempt to restructure social life. Distinctions between the different social and religious groups were blurred in different ways in the two cases. In Ireland, distinctions run along lines of sociability; populations were divided according to their affiliation to churches, schools and neighbourhoods. Most of these were distinctively Catholic or Protestant, thus creating a gap between the religious communities. The religious communities might have pursued a different social life, but the small size alone of Irish local populations guaranteed personal encounters. At the time of the excesses, the perpetrators knew well whom they were attacking.

The Polish case was somewhat more complex. Poles, Ukrainians and Jews mostly spoke their respective languages and sometimes even differed in appearance. Orthodox Jews, distinctive in their traditional clothes, often fell prey to assaults. But, again, the most important cleavages were religious, since the Polish population was almost exclusively Roman Catholic, and the Ukrainian population Orthodox Catholic. While these two groups until the First World War still mixed socially and sometimes intermarried, the Jewish population - at least the practising segment - was far more alienated. ${ }^{48}$ Local perpetrators were familiar with the community and likely to know their victims. However, also distinct in the Polish case was the impact of paramilitaries from outside the communities where the violence was committed. While in the

47 Natalie Zemon Davis, 'The Rites of Violence: Religious Riots in Sixteenth-Century France', Past and Present, 59 (May I973), 5I-9I, 82.

48 Philipp Ther, 'Chancen und Untergang einer multethnischen Stadt: Die Beziehungen zwischen den Nationalitäten in Lemberg in der ersten Hälfte des 20. Jh', in Philipp Ther and Holm Sundhaussen, eds., Nationalitätenkonflikte im 20. Jahrhundert. Ursachen von inter-ethnischer Gewalt im Vergleich (Wiesbaden: Harrassowitz 200I), I23-45, I26. 
Irish case the members of the IRA were usually connected to their families and communities, ${ }^{49}$ Polish paramilitaries were composed both of local volunteers and of a high number of mobile ex-veterans and adventurers. Dynamics of civil war and national uprising mixed with the dynamic of a war of conquest, new social borders being securing by paramilitaries who were strangers to the regions and their communities. Soldiers of Haller's Army committed a significant number of the assaults against civilians in the eastern territories. ${ }^{50}$ Their combatants included Polish prisoners of war, deserters from the armies of the Central Powers and volunteers of Polish origin from the United States, France and Britain. On their way to the east their troops were complemented by large numbers of Polish volunteers, who had either just left the German or Austrian army, or who not been mobilised during the First World War. This calls into question the interpretation of old-fashioned traditional ethnic and sectarian violence. It is likely that a cultural shock similar to that described by Liulevicius in the case of German soldiers in the east was at work, in that these paramilitaries encountered a strange landscape with unknown people and customs. The threat of the unfamiliar may have provoked a surge of violence. To enforce their own understanding of the new national community, the paramilitaries employed semiotic forms of violence against those 'outsiders' as a political message.

One criterion to define those outsiders was religion. Both Poland and Ireland had been governed by empires of denominations different from their own (Protestant Britain, Protestant Germany, Orthodox Russia, the multi-ethnic and multi-religious Habsburg empire being a special case). Independence movements during the late nineteenth century had been driven by cultural nationalism, with particular emphasis on the markers of language, education and religion. In the absence of a recognised political nationality, the affiliation to a church became crucial in defining who was Irish or Polish - and who was not. Catholicism was highly influential on national self-perception, public opinion and cultural life. Traditional nationalist concepts of both 'Irishness' and 'Polishness' implied Catholicism and excluded religious minorities (in the Polish case Jews, (Prussian) Protestants, (Ukrainian) Orthodox, and in the Irish case Protestants) or at least rendered their participation in the national project problematic. While government armies are set up according to citizenship, paramilitary mobilisation and paramilitary violence deepened religious and denominational cleavages.

Although high levels of violence at the local level might seem unusual, as they erupted between neighbours, who in many cases had formerly lived in relative harmony, even small communities presented major divisions. Daily life was to a large extent lived according to religious communities. Belonging to different religions meant, on a local level, not only separation of religious practice but also of many related aspects of social life, such as reading groups, charitable work, youth groups

49 For the social background of IRA combatants and also on the question of the reliability of witness statements, see Eve Morrison, 'Identity, Allegience, War and Remembrance: The Bureau of Military History and the Irish Revolution, I9I3-I923', Ph.D. dissertation, Trinity College Dublin (forthcoming).

50 Kapiszewski, 'Controversial Reports', 270, 276. 
and any kind of social meeting after church. It was not only about religious violence, it was about the discourse and practice of social estrangement, which allowed people to view their neighbours as enemies. Furthermore, as Stanley Tambiah pointed out, exactly the former coexistence might lead to extremely unrestrained violence, as "hatred and repudiation are unleashed in denial of "confusions" or lack of firm partitions between the antagonists'. ${ }^{51}$

Therefore, in both countries, although to a different extent, violence was linked to an estrangement within communities. Not only the victims but also the perpetrators were alienated from their community, by their daily military life, experience of violence and mobility. This loosened the moral framework that normally bound communities and enabled the emergence of a 'war culture' that gave rise to excesses. ${ }^{52}$

In Poland, antisemitism increased in the war years because the Jewish population was suspected of supporting the Habsburg authorities in suppressing Polish nationalism. The same suspicion was applied to the Ukrainian population, which was regarded as the 'pet dog' of the partition power. The gap between the religious communities broadened in I9I 7 and I9I 8 with the events of the Russian Revolution and the rising independence movement, on both the Ukrainian and the Polish sides. The massive growth of antisemitic violence was sudden, but seems to fit perfectly into a long tradition of Polish-Ukrainian or Polish-Lithuanian conflicts on the one hand and of antisemitism on the other hand. Some of the assaults displayed classic forms of 'staged' antisemitic violence, ${ }^{53}$ such as excesses committed by enraged mobs, especially in Kraków and Rzeszów. The events in these cities resembled 'traditional' forms of antisemitic violence. ${ }^{54}$ Most familiar were the antisemitic excesses that took place in connection with the Polish-Ukrainian war and especially during and after the battle for Lwów. Both sides, Ukrainians and Poles, accused each other of responsibility. ${ }^{55}$ Another hot spot for antisemitic violence was the Lithuanian-Polish city of Vilna. Among the multi-ethnic population, the Poles called for annexation to an independent Poland and in I9I 8 set up the Samoobrona Wileńska (self-defence of

51 Stanley Tambiah, Levelling Crowds, 276.

52 Horne and Kramer, 'Soldiers and Civilians', I62.

53 Helmut Walser Smith, The Continuities of German History: Nation, Religion, and Race across the Long Nineteenth Century (Cambridge University Press, 2008), ch. 4. Many accounts of beatings, humiliation and so on correspond to Walser Smith's analyses of traditional antisemitic violence as carried out in a theatrical form and usually refraining from major assaults. See BNSpecjalny (Rękopisy), Rps BN akc I03I2, Brochocki, Wspomnienia wojenne, 9. BN Specjalny (Rękopisy), Rps BN akc I03I2, Brochocki, Wspomnienia wojenne, 80-8I.

54 'Like a thunderstorm peasants came into the Galician towns, and especially into Kraków and Rzeszów, where armed peasants insulted Jews in their houses and flats and beat them up and plundered their shops'. Żydowski Instytut Historyczny - Archiwum Pamiętniki Żydów Warszawa(ŻIH), Gmina Kraków [I9I9] Korespondencja dotycza antyżydowskich, [...wielka Krakowie] i innych miastach, Dokument III, 3 and 4 .

55 '[I]n the same Lwów were [crossed out, handwritten: the Ukrainians committed] a Jewish pogrom in Lwów.' 'Polish journals wrote, that the Pogrom had been committed by Ukrainians, we should not trust this, having other information [sic!].' ZIH Warszawa, 302/204 Autor: Weksztejn Anatol, Czasokres: I874-I945 r. łowicz, Sochaczew i powiaty, miasta: Charków, Wilno, Lwów, Lublin, Warszawa, 89-90 (9I-92). 
Vilna). ${ }^{56}$ The Samoobrona was fiercely nationalistic and suspected any member of the Jewish community of Vilna of anti-Polish sentiments. ${ }^{57}$ Jews were accused of using any opportunity to associate with Poland's enemy: with the Russians in I9I4, with the Austrians in I9I 8 after Russia's defeat, and later with the Ukrainians. ${ }^{58}$ Jews were accused of 'turning their coat with the weather' and of speaking whatever language they considered politically suitable..$^{59}$

Central to the excesses was also the reproach of faceless anonymity to the enemy. In civil and guerrilla war, the enemy is regarded as treacherous and the civilian becomes a potential combatant in disguise, a franc-tireur, a supporter of the enemy, a traitor, or a terrorist. Both in Poland and Ireland, each side in the conflict nurtured its own rumours and myths about franc-tireurs. ${ }^{60}$ The introduction of newly established formations added to the confusion. Repeatedly, witness statements to the American Commission on Ireland refer to crimes committed by agents, who 'did not appear to be a regular Soldier, nor ... [the] customary Black and Tan'. ${ }^{61}$ The British equally perceived the IRA as faceless terrorists who could easily vanish among the supporting civilian population. Describing an ambush by allegedly fifty men in County Galway in November I920, the Head Constable James Healey seems to have been even more upset that 'fifty young men had all vanished into peaceful workers over the countryside' than he was about the ambush itself. ${ }^{62}$ This insecurity about who was civilian and who was combatant continued into the Irish Civil War.

The same 'facelessness' and blurring of distinctions between combatant and noncombatant were described in Poland: Polish volunteers often fought in civilian clothes. ${ }^{63}$ The distinctions between regular army, paramilitaries, armed peasants and

56 Biblioteka Narodowa Zbiór Specjalny (Rękopisy), Rps BN akc I03 I2, Brochocki: Wspomnienia wojenne, 3 .

57 'Jews had no friends among the Poles, least among the Vilna Ulans. Too well known was their enthusiastic attitude towards the bolshevists, greeting them as victors, and the cool expression in their faces when luck was on the Polish side. While marching into a Jewish shtetl, [we/they] liked to sing [Antisemitic songs].' BN Specjalny (Rękopisy), Rps BN akc I03 I2, Brochocki Wspomnienia wojenne, 7I.

58 L'viv, DALO, f. 257, op. Ic, spr. 44 [Donecenie komandavanija Lwowskim brigadi o jevrenickich pogromach w I9I 8 wo Lwowie] Teczka Nr. 49, Odpis nr. Ewid. 4 Komenda brygady lwowskiej. Akta z roku I9I9. Relacje o wypadkach w dzielnicy żydowskiej we Lwowie i listopadzie I9I8 r, 3 .

59 'From igos on it became fashionable for Jews to speak Polish. Russian was now the language of the suppressor, 'tsarist', and reactionary ... Everything was different in I9I8. The Polish language was the language of Polish nationalists, who longed for Polish independence. For Jews this independence was not necessary ... Rich and poor Jews were favourable towards the communists, Russian was the revolution's tongue, and therefore now all Jews spoke Russian.' 'With the bolshevist invasion of Vilna the Polish language vanished from the centre and into the suburbs. The new ruling language was Russian, as in tsarist times, but only because not all of the population spoke Jewish.' BN Specjalny (Rękopisy), Rps BN akc I03 I2, Brochocki, Wspomnienia wojenne, 3-3a.

60 Horne and Kramer, 'Soldiers and Civilians', I63. For a more detailed discussion see John Horne and Alan Kramer, German Atrocities, 1914: A History of Denial (New Haven: Yale University Press, 200I), I 49-50.

61 Imperial War Museum, London (IWM) 2949 Misc I75 (2658), Account of the life of Major General Sir H. H. Tudor, KCB CMG (I87I-I965), 29.

62 Ibid., 3 I 4.

63 L'viv, DALO, f. 257 , op. Ic, spr. 44., 5. 
self-defence units on the one hand and armed gangs and bandits on the other were so blurred that they could even overlap. ${ }^{64}$ In Poland, the Jewish population was often accused of acting as franc-tireurs. The collective self-suggestion of being attacked illegally in a partisan war contributed to the escalation of violence. ${ }^{65}$ Rumours of enemy outrages often provoked the same outrages in turn and thus became self-fulfilling. ${ }^{66}$

Violence against minorities in both countries was justified by the accusation of political betrayal. Protestants in Ireland had a difficult time proving that they neither supported the British forces nor opposed an independent Ireland. As Tom Barry, one of the most prominent guerrilla leaders of the IRA during the war of independence, put it, 'We never killed a man or interfered with a man because of his religion . . . but we had to face up to the facts.' ${ }^{67}$ The mistrust was buried deep: any Catholic in the North was usually believed to be a 'Sinn Féiner', while Protestants living in the South were believed to be loyalists (and often were). ${ }^{68}$ Thus religion functioned as a political cleavage, and the resulting violence was politically and nationally motivated. ${ }^{69}$ The smallest rumours could lead to lethal results. Rumours about Jewish disloyalty and treason in Poland were manifold. In Lwów, stories that the Jewish population joined the Ukrainian forces provoked aggression, ${ }^{70}$ as did the news that Jewish military patrols had been set up. ${ }^{71}$ The impression that the Jewish population had betrayed their promise of remaining neutral ${ }^{72}$ was now mixed with new social-Darwinist ideas about the organic body of the nation in which the Jews would always remain foreign. ${ }^{73}$ The fact that the Jewish minority modified these traditional patterns of behaviour and actively set up their own militia only added to the spiralling violence. ${ }^{74}$

64 As this note, taken during the battle of Lwów, states: 'Two Jews killed by bandits, who at the same time were soldiers of the Polish army'. L'viv, DALO, f. 257, op. Ic, spr. 44, 5.

65 Horne, Kramer, Atrocities, I24; Horne and Kramer, 'Soldiers and Civilians', I 57.

66 Tambiah, Levelling Crowds, 237.

${ }^{67}$ RTE interview (tape in possession of Donal O'Donovan), quoted in Hart, IRA and Its Enemies, 273.

$68 \mathrm{Jim}$ McDermott, Northern Divisions: The Old IRA and the Belfast Pogroms, 1920-1922 (Belfast: BTP, 200I), 35 .

69 Andreas Wimmer and Conrad Schetter: 'Ethnische Gewalt', in Wilhelm Heitmeyer and John Hagan, eds., Internationales Handbuch der Gewaltforschung (Wiesbaden: Westdeutscher Verlag, 2002), 3 I3-29, 3 I 4 .

70 Ossolineum, I2925/III r 885-I939. Baczyński: 'Pamiętniki', Mikrofilm 2429, Zeszyt 5, i89-90 (9 Nov. I9I8).

71 'I do not understand why the Jews would so meanly reject Polishness (polskość)? Especially in this town whose inhabitants always defended them in the worst moments? In this case, the Jews made the wrong call - and the result will be falling back on them in a fatal way!' Ossolineum, I2925/III i 88 5-I939. Baczyński: 'Pamiętniki', Mikrofilm 2429, zeszyt 6: I4 Nov. I9I 8 - 20 Oct. I9I9, Lwów, I-6 (I4 Nov. I9I8).

72 Referring to a written agreement with the Polish command from Io Nov. I9I 8 that Jewish militia would join the fighting on neither the Polish nor the Ukrainian side. L'viv, DALO, f. 257, op. Ic, spr. 44,6 .

73 'Jews are a great evil for the Polish organism. Poles they will never be! Even those who seem assimilatory, who declare that they love Poland - they are no Poles ... They only do it to serve their own interest.' Ossolineum, I2925/III I885-I939. Baczyński: 'Pamiętniki', Mikrofilm 2429, zeszyt 6, I-6 (I4 Nov. I9I8).

74 Walser Smith, Continuities, I 55. 


\section{Conclusion}

Paramilitary formations in post-war Ireland and in Poland defined themselves as legitimate forces. The former authorities were regarded as illegitimate and incapable of maintaining order. Therefore members of these irregular formations saw themselves as pre-military rather than paramilitary forces. This led them to believe that their actions would be legitimised by their future function, thus loosening restraints. They were not revolutionary in terms of their ideologies; the only revolution they aimed to achieve was independence, and the defeat of the occupying powers and of all enemies opposed to this. In their own understanding, they were defending their country. Arson, hair-shearing and executions of those who appeared to resist them were expressions of a para-state or pre-state justice..$^{75}$ This is all the more true for Ireland, where both burnings and hair cutting had their prequel not only in sectarian outrages, but also in the quasi-official reprisal policies of the British forces.

Betrayal was regarded as political in both cases. Since nationality in both countries was closely linked to Catholicism, the reproach of betrayal was inseparable from its religious (and ethnic) notion. In most cases, however, social distinctions were as important as religious or ethnic ones. The First World War triggered the violent discharge of an explosive combination of political ideologies and religious-ethnic stereotypes in the uncertain post-war world, in which the state in many newly independent countries had insufficient authority to contain and to limit violence.

Aggressive and nationalist discourse went hand in hand with the described forms of excesses. Violence indeed proved to be part of the discourse out of which the national community was fashioned and the symbolic use of violence both marked and expressed the social, ethnic and religious dichotomies that underlay national identities. By employing forms of violence that served as a symbol and a message, the nationalist paramilitaries manifested this discourse in the social communities in which they were embedded or to which (in the Polish case) they came from outside. In this sense, semiotics of paramilitary violence helped to construct the nation.

75 Consider also that in this period the IRA 'police' regularly arrested citizens prosecuted by the underground Dáil Courts (Borgonovo, Spies, 29 (CI Report for Cork (City and East Riding), October I920, CO 904/I I3), or that men were tarred and feathered for petty theft. Borgonovo, Spies, 58 . 